\title{
Oral health actions in the primary health care network of northeastern brazil in relation to oral cancer
}

\author{
Ações de saúde frente ao câncer bucal na \\ atenção básica do nordeste brasileiro
}

\author{
Larycia Vicente RODRIGUES ${ }^{1}$ iD 0000-0002-4905-8161 \\ Isabella Lima Arrais RIBEIRO² iD 0000-0001-6538-6811 \\ Ane Polline Lacerda PROTASIO ${ }^{1}$ iD 0000-0003-2895-436X \\ Ana Maria Gondim VALENÇA ${ }^{3}$ iD 0000-0001-8460-3981 \\ Eufrásio de Andrade LIMA NETO ${ }^{1}$ iD 0000-0003-2397-7394
}

\section{ABSTRACT}

Objective: To describe oral health actions against oral cancer promoted by Primary Health Care Teams in northeastern Brazil. Methods: This is a descriptive and inferential study based on data related to detection, referral, registration, follow-up and documents related to these actions in the External Evaluation of the 1st and 2nd Program for Improving Access and Quality of Primary Care Cycles. Results: Overall, 5,599 and 7,700 teams were evaluated, respectively, in the first and second cycles, with the highest and lowest concentrations in the states of Bahia / Maranhão and Bahia / Sergipe. In all, 58.9\% / 79.7\% Health Teams conducted campaigns to detect oral lesions and referred suspected cases of oral cancer, and $43.9 \%$ / $23 \%$ of them recorded and followed suspicious / confirmed cases and only $20.7 \% / 16.2 \%$ had documents proving these records in the respective cycles. There was statistical significance in the comparisons of actions and the evaluation cycles $(p \leq 0.01)$. Conclusion: Health teams in northeastern Brazil need to improve actions related to detection, referral, registration, follow-up and verification of oral health documents related to oral cancer.

Indexing terms: Family health. Health services. Health services accessibility. Mouth neoplasms. Oral health.

\section{RESUMO}

Objetivo: Descrever as ações em saúde bucal frente ao câncer de boca promovidas pelas Equipes de Saúde da Atenção Básica do nordeste brasileiro. Métodos: Estudo descritivo e inferencial a partir de dados referentes à detecção, encaminhamento, registro, acompanhamento e documentos comprovatórios relacionados a estas ações relativos ao $1^{\circ}$ e $2^{\circ}$ Ciclo de Avaliação Externa do Programa de Melhoria do Acesso e da Qualidade da Atenção Básica. Os dados foram analisados pelos testes Qui-Quadrado e McNemar (a=0,05). Resultados: Foram avaliadas 5.559 e 7.700 equipes, respectivamente, nos $1^{\circ}$ e $2^{\circ}$ ciclos, sendo, a maior e menor concentração na Bahia/Maranhão e Bahia/Sergipe. 58,9\%/79,7\% das Equipes realizam campanhas para detecção de lesões bucais e encaminham

\footnotetext{
$\boldsymbol{\nabla v} \nabla$

1 Universidade Federal da Paraíba, Departamento de Estatística. Cidade Universitária, s/n., 58051-900, João Pessoa, PB, Brasil. Correspondência para / Correspondence to: LV RODRIGUES. E-mail: <larycia_rodrigues@hotmail.com>.

2 Universidade Federal da Paraíba, Departamento de Odontologia. João Pessoa, PB, Brasil.

${ }^{3}$ Universidade Federal da Paraíba, Departamento de Clínica e Odontologia Social. João Pessoa, PB, Brasil.

$\boldsymbol{\nabla v} \nabla$

How to cite this article

Rodrigues LV, Ribeiro ILA, Protasio APL, Valença AMG, Lima Neto EA. Oral health actions in the primary health care network of northeastern brazil in relation to oral cancer. RGO, Rev Gaúch Odontol. 2019;67:e20190027. http://dx.doi.org/10.1590/1981-86372019000273565
} 
os casos suspeitos de câncer de boca. Além disso, 43,9\%/23\% delas registram e acompanham os casos suspeitos/confirmados e apenas 20,7\%/16,2\% possuem documentos que comprovem esses registros, nos respectivos ciclos. Houve significância estatística nas comparações das ações e os ciclos de avaliação $(p \leq 0,01)$. Conclusão: As Equipes de Saúde na região nordeste necessitam melhorar as ações referentes à detecção, encaminhamento, registro, acompanhamento e documentos comprovatórios em saúde bucal frente ao câncer de boca.

Termos de indexação: Saúde da família. Serviços de saúde. Acessos aos serviços de saúde. Saúde bucal. Neoplasias bucais.

\section{INTRODUCTION}

Currently, the focus of health care in Brazil is directed to reorganize Primary Care (AB). The Family Health Program (PSF), which was created in 1994 and became a strategy, the Family Health Strategy (ESF), has had an impact on the health structure of the country by offering actions and services to improve care for citizens Brazilians, as well as new directions for $A B[1,2]$.

In the field of oral health, especially after the institution of the National Oral Health Policy (PNSB), in 2004, the government had greater responsibility for oral health [3]. The incorporation of Oral Health Teams (ESB) in ESF in 2000 and its improvement in 2013 due to additional financial incentives, strengthened $A B$ principles and health promotion in the oral health care offered to the population [4].

In this perspective, the identification of cases of oral cancer is an action developed in AB. Oral Cancer is a name used to group neoplasms that reach lips and oral cavity. Its risk factors include, mainly, smoking, alcoholism, human papillomavirus (HPV), and exposure to solar radiation [5-7]. For the year 2018, the National Cancer Institute (INCA) estimated a total of 11,200 new cases of oral cancer in men and 3,500 in women. In the northeastern region of Brazil, this pathology occupies the fifth place of cancer cases among men (6.72 / 100 thousand) and the eleventh among women (3.12 / 100 thousand) [5].

It is estimated that this type of cancer reaches $80 \%$ of the population in more than 20 million new cases by 2025 . Therefore, knowledge about its epidemiology is a necessary condition to monitor and develop strategies for health promotion, prevention and control of its risk factors. A study showed that the most important factor negatively related to the survival of patients with oral neoplasm is the late diagnosis [8], and although the oral cavity is an easily inspected region, health professionals report the lack of experience regarding the identification of the cancerous lesion and the performance of biopsy procedure [9], as items necessary to establish an early diagnosis.
In this context, and with the relevance that $A B$ has acquired, both in the governmental policy agenda and in the scientific area, the Ministry of Health (MS), through the Saúde Mais Perto de Você strategy, implemented the Program for Improved Access and Quality of Basic Attention (PMAQ-AB), with the purpose of inducing the expansion of the population's access to services, improving working conditions and quality of care, as well as investing in the training of professional teams $[10,11]$, which effectively contributes for changes in the primary care fundamentals $[12,13]$

Therefore, the aim of this study was to describe from data of the first and second PMAQ-AB cycles, oral health actions regarding oral cancer promoted by Primary Care Health Teams acting in the northeastern region of Brazil.

\section{METHODS}

The present study, with sectional, descriptive and inferential design and quantitative approach, used secondary data provided by the Ministry of Health, related to the external evaluation of the 1st and 2nd PMAQ-AB cycles collected between 2012 and the first semester of 2013, for the first cycle, and from November 2013 to July of 2014, for the second cycle. A total of 17,482 Primary Health Care Teams were involved in the first PMAQ-AB cycle, referring to 3,967 Brazilian municipalities, of which 12,436 had Oral Health Teams, and the second cycle involved 30,522 teams referring to 5,077 municipalities, of which 19,946 ESB [14]. The sample consisted of all Primary Care Health Teams that participated in the external evaluation of the first ( $n=5.559)$ and second cycles $(n=7,700)$, in the nine (9) states of the Northeast Region, which had information regarding the variables of interest.

The project was approved by the Ethics Research Committee (CEP) of the Federal University of Rio Grande do Sul (UFRGS) under number 21904, in March 2012. 
The variables of interest were: Carrying out campaigns to detect oral lesions and referral of suspected cases of oral cancer; Registration and follow-up of suspected / confirmed cases; and documents proving such records, as described below:

- Item I| 36.8 in the first cycle (Does the Oral Health Team perform campaigns to detect oral lesions and refer suspected cases of oral cancer? Yes or No); equivalent to Item VI 17.3 in the second cycle (Does the Oral Health Team perform actions to prevent and detect oral cancer? Yes or No);

- Item 36.9 (Does the Oral Health Team record and monitor suspected / confirmed cases of oral cancer? Yes or No); equivalent to Item VI 17.1.G in the second cycle (Does the Oral Health Team have records of suspected / confirmed cases of oral cancer? Yes or No);

- Item 39.9 / 1 (Is there a document that proves? Yes or No); equivalent to Item VI 17.3 / 1 (Is there a document that proves? Yes or No).
Although the questions do not present identical wording, they had the same purpose, that is, the question of item II.36.8 resembles VI.17.3, both of which seek to promote the detection and early treatment of oral cancer, as well as of item II 36.9 and VI.17.2, which seek to monitor confirmed cases.

In order to evaluate the association between the variables of interest in the states of northeastern Brazil, the Chi-square test was used when the comparison was established in a single cycle, and the McNemar test ( = $5 \%$ ) in both cycles. A 95\% Confidence Interval (Cl) was adopted and analyses were performed using the IBM SPSS (21.0) 15 software [15].

For inferential analysis, there were dichotomous (yes or no) and absent responses. The latter were interpreted as "No" because, in the PMAQ-AB Certification Score, the percentage for this response was also zero percent. The variable Registry and follow-up of suspected / confirmed cases was not evaluated between the first and second cycle, because in the second cycle, the response options

Table 1. Description of the variables of interest used in the assessment of oral health in relation to oral cancer in the states of Northeastern Brazil in the first PMAQ-AB cycle, 2011/2012.

\begin{tabular}{|c|c|c|c|c|}
\hline State & $\begin{array}{l}\text { Number of teams that } \\
\text { joined PMAQ-AB\% (n) }\end{array}$ & $\begin{array}{l}\text { Campaign to detect oral lesions } \\
\text { and referral of suspected oral } \\
\text { cancer cases \% (n) }\end{array}$ & $\begin{array}{l}\text { Registration and follow-up of } \\
\text { suspected / confirmed oral cancer } \\
\text { cases } \%(n)\end{array}$ & $\begin{array}{l}\text { Document proving the registration } \\
\text { and follow-up of suspected / } \\
\text { confirmed oral cancer cases. \% (n) }\end{array}$ \\
\hline Bahia & $27.6 \%(1.534)$ & $\begin{aligned} \text { Yes } & =52.67(808) \\
\mathrm{No} & =47.33(726)\end{aligned}$ & $\begin{array}{c}\text { Yes }=2.67(41) \\
\text { No }=97.33(1493)\end{array}$ & $\begin{array}{l}\text { Yes }=13.17(202) \\
\mathrm{No}=86.83(1332)\end{array}$ \\
\hline Maranhão & $2.0 \%(112)$ & $\begin{array}{l}\text { Yes }=47.32(53) \\
\text { No }=52.68(59)\end{array}$ & $\begin{array}{c}\text { Yes }=1.79(02) \\
\mathrm{No}=98.21(110)\end{array}$ & $\begin{array}{l}\text { Yes }=22.32(25) \\
\mathrm{No}=77.68(87)\end{array}$ \\
\hline Piauí & $\begin{array}{l}6.7 \% \\
(371)\end{array}$ & $\begin{array}{l}\text { Yes }=56.60(210) \\
\text { No }=43.40(161)\end{array}$ & $\begin{array}{l}\text { Yes }=9.43(35) \\
\mathrm{No}=90.57(336)\end{array}$ & $\begin{array}{c}\text { Yes }=6.47(24) \\
\mathrm{No}=93.53(347)\end{array}$ \\
\hline Rio Grande do Norte & $\begin{array}{l}7.4 \% \\
(412)\end{array}$ & $\begin{array}{l}\text { Yes }=68.93(284) \\
\text { No }=31.07(128)\end{array}$ & $\begin{array}{c}\text { Yes }=5.83(24) \\
\mathrm{No}=94.17(388)\end{array}$ & $\begin{aligned} \mathrm{Yes} & =26.46(109) \\
\mathrm{No} & =73.54(303)\end{aligned}$ \\
\hline Sergipe & $\begin{array}{l}4.4 \% \\
(247)\end{array}$ & $\begin{array}{c}\text { Yes }=63.16(156) \\
\text { No }=36.84(91)\end{array}$ & $\begin{array}{c}\text { Yes }=0.40(01) \\
\mathrm{No}=99.60(246)\end{array}$ & $\begin{array}{l}\text { Yes }=16.60(41) \\
\mathrm{No}=83.40(206)\end{array}$ \\
\hline Total & & & 100 (5559) & \\
\hline
\end{tabular}


were different from those used in the first one. As in the second cycle, an instrument directed to Oral Health Teams was instituted.

It is worth noting that the response "Does not know if there is any case in the territory" was not tested between cycles because this question was inserted in the questionnaire of the second evaluation cycle.

\section{RESULTS}

Of the 5,559 Primary Care Health Teams assessed in the 1st PMAQ-AB cycle, the highest concentration was in the state of Bahia (27.6\%) and the lowest in Maranhão (2.2\%) (table 1).

It was verified that $58.9 \%$ of Primary Health Care Teams carry out campaigns to detect oral lesions and refer suspected oral cancer cases. In addition, 43.9\% of them record and monitor suspected / confirmed cases, but only $20.7 \%$ have documents that prove these records. It was found that there is a statistically significant difference among variables of interest in the nine states of northeastern Brazil, with predominance of campaign actions to detect oral lesions and referral of suspected oral cancer cases, but without registration of activities carried out as well as documents proving their accomplishment ( $p$ $\leq 0.05$ ) (table 2).

Of the 7,700 Primary Health Care Teams that participated in the external evaluation of the $2^{\text {nd }}$ PMAQ$A B$ cycle, Bahia (BA), again, stands out with the largest number $(21.3 \%)$, and Sergipe (SE) with the lowest (2.9\%) (table 3).

In this cycle, the performance of campaigns for the detection of oral lesions was mentioned by $79.7 \%$ of teams; the registry of the referral of suspected oral cancer cases was mentioned by $23 \%$ of them; however, when questioned about the existence of documents of registry and follow-up of suspected / confirmed oral cancer cases, only $16.2 \%$ of teams were able to present it. It is noteworthy that although the number of teams was higher than in the previous evaluation, the representative percentage of variables was shown to be lower than expected when comparing the two cycles. In the same way as in the 1st cycle, in the $2^{\text {nd }}$ cycle, variables behaved differently among the nine states, that is, without registration or documents proving the accomplishment of the actions proposed by PMAQ-AB ( $p \leq 0.05)$ (table 4).

Finally, when comparing the three variables from one cycle to another, it was observed that there is a differentiated behavior between study variables and the nine states of northeastern Brazil $(p \leq 0.05)$ (table 5).

\section{DISCUSSION}

The present study aimed to identify the existence of differences in oral health services and actions promoted by the Primary Care in relation to oral cancer in nine states of northeastern Brazil based on an evaluation of data made available by Primary Health Care Teams who joined the PMAQ-AB. This study also evaluated inequalities among states from the first and second PMAQ-AB cycles, with particular interest in the evaluation of campaigns for the detection of oral lesions and referral of suspected oral cancer cases, in addition to the verification of registry and follow-up of suspected / confirmed cases and the presence of documents proving these records.

Table 2. Description of variables of interest among states of northeastern Brazil in the years 2011/2012 according to the first PMAQ-AB cycle.

\begin{tabular}{|c|c|c|}
\hline Variable of interest & Yes & No \\
\hline Campaign to detect oral lesions and referral of suspected oral cancer cases *. & $3.277(58.9 \%)$ & $2.282(41.1 \%)$ \\
\hline Registration and follow - up of suspected / confirmed oral cancer cases*. & $2.438(43.9 \%)$ & $3.121(56.1 \%)$ \\
\hline Document proving the registration and follow-up of suspected / confirmed oral cancer cases*. & $1.148(20.7 \%)$ & $4.411(79.3 \%)$ \\
\hline Total & & \\
\hline
\end{tabular}


Table 3. Description of variables of interest used in the oral health evaluation regarding the presence of oral cancer by states of northeastern Brazil in the $2^{\text {nd }}$ PMAQ-AB cycle, 2013/2014.

\begin{tabular}{|c|c|c|c|c|}
\hline State & Number of ESB that joined PMAQ-AB \% (n) & V1 \% (n) & V2 \% (n) & V3 \% (n) \\
\hline Yes & - & $71.08(381)$ & $23.69(127)$ & $15.49(83)$ \\
\hline No & - & $28.92(155)$ & $22.01(118)$ & $84.51(453)$ \\
\hline Unknown & - & - & $54.29(291)$ & - \\
\hline Yes & - & $82.10(1348)$ & $20.46(336)$ & $13.76(226)$ \\
\hline No & - & $17.90(294)$ & $13.64(224)$ & $86.24(1416)$ \\
\hline Unknown & - & & $65.90(1082)$ & - \\
\hline Ceará & $14.8(1137)$ & & & \\
\hline Unknown & - & - & $52.51(597)$ & - \\
\hline Maranhão & $4.8(381)$ & & & \\
\hline Yes & - & $66.67(254)$ & $6.56(25)$ & $3.15(12)$ \\
\hline No & - & $33.33(127)$ & $29.92(114)$ & 96.85 (369) \\
\hline Unknown & - & - & $63.52(242)$ & - \\
\hline Paraíba & $14.1(1084)$ & & & \\
\hline Yes & - & 77.95 (845) & $19.56(212)$ & 13.75 (149) \\
\hline No & - & 22.05 (239) & $22.60(245)$ & 86.25 (935) \\
\hline Piaui & $10.1(780)$ & & & \\
\hline Yes & - & $77.56(605)$ & $12.56(98)$ & $7.44(58)$ \\
\hline No & - & $13.21(175)$ & $23.59(184)$ & $92.56(722)$ \\
\hline Unknown & - & - & $63.85(498)$ & - \\
\hline Rio Grande Norte & $10.1(776)$ & & & \\
\hline Yes & - & $86.73(673)$ & $32.60(253)$ & 25.39 (197) \\
\hline No & - & $13.27(103)$ & $15.08(117)$ & 74.61 (579) \\
\hline Unknown & - & - & $52.32(406)$ & - \\
\hline Sergipe & $2.9(223)$ & & & \\
\hline Yes & - & $79.82(178)$ & $32.29(72)$ & $19.73(44)$ \\
\hline No & - & $20.18(45)$ & $27.80(62)$ & 80.27 (179) \\
\hline Unknown & - & - & 39.91 (89) & - \\
\hline
\end{tabular}

Legend: SI = No Information; V1 = Campaign to detect oral lesions and referral of suspected oral cancer cases; V2 = Registration and follow-up of suspected / confirmed oral cancer cases; $\mathrm{V} 3=$ Document proving the registration and follow-up of suspected / confirmed oral cancer cases. 
Table 4. Characterization of the variables of interest among states of northeastern Brazil in years of 2013 and 2014 and the second PMAQ-AB cycle.

\begin{tabular}{|c|c|c|c|}
\hline Variable of interest & Yes & No & $\begin{array}{l}\text { Does not know if there is } \\
\text { any case in the territory }\end{array}$ \\
\hline Campaign to detect oral lesions and referral of suspected oral cancer cases *. & $6.136(79.7 \%)$ & $1.564(20.3 \%)$ & - \\
\hline Registration and follow - up of suspected / confirmed oral cancer cases *. & $1.770(23 \%)$ & $1.535(19.9 \%)$ & $4.395(57.1 \%)$ \\
\hline Total & & 7.700 & \\
\hline
\end{tabular}

*Variables that presented p-value $\leq 0.05$

Chi-square test.

Table 5. Comparison of variables of interest among states of northeastern Brazil between the first and second PMAQ-AB cycles.

\begin{tabular}{|c|c|c|c|c|}
\hline \multirow{2}{*}{ Variable of interest } & \multicolumn{2}{|c|}{ First cycle } & \multicolumn{2}{|c|}{ Second cycle } \\
\hline & Yes & No & Yes & No \\
\hline Campaign to detect oral lesions and referral of suspected oral cancer cases*. & $\begin{array}{c}3.277 \\
(58.9 \%)\end{array}$ & $\begin{array}{c}2.282 \\
(41.1 \%)\end{array}$ & $\begin{array}{c}6.136 \\
(79.7 \%)\end{array}$ & $\begin{array}{c}1.564 \\
(20.3 \%)\end{array}$ \\
\hline Document proving the registration and follow - up of suspected / confirmed oral cancer cases*. & $\begin{array}{c}1.148 \\
(20.7 \%)\end{array}$ & $\begin{array}{c}4.411 \\
(79.3 \%)\end{array}$ & $\begin{array}{c}1.050 \\
(13.6 \%)\end{array}$ & $\begin{array}{c}6.650 \\
(86.4 \%)\end{array}$ \\
\hline Total & \multicolumn{2}{|c|}{5.559} & \multicolumn{2}{|c|}{7.700} \\
\hline
\end{tabular}

*Variables that presented p-value $\leq 0.05$. McNemar Test.

Since cancer is generally considered to be one of the most important public health problems worldwide, especially in the context of developing countries, as in the case of Brazil, the evaluation of its care is fundamental to review and guide actions [16].

Thus, the performance of this study for the northeastern region of Brazil was due to the magnitude of its oral health organization. Of the 1,775 municipalities with family health team, 1,753 have oral health teams, 12,681 of which are accredited by the Ministry of Health, 11,395 are enrolled in the system and 10,691 are enrolled in Modality I while 404 in Modality II, 335 registered and 324 implemented until October 2016 [17].

Although the northeastern region of Brazil has the largest number of primary care teams [18], this does not mean that health actions and services in all of them are similar. Bahia, for example, has the largest number of oral health teams among northeastern states, but it is the region where oral cancers are diagnosed later, implying a greater number of deaths due to pathology [19]. In Sergipe, there are 9.28 cases of oral cavity cancer per 100,000 inhabitants, with the highest oral cancer rates for the northeastern region [20], and, according to the present study, this state showed the least number of recordings or follow-up of suspected or confirmed oral cancer cases, with only one case recorded in the data referring to the evaluation of the 1st PMAQ-AB cycle. In the state of Pernambuco, oral cancer detection campaigns, as well as the offer of prevention and follow-up services, are still deficient and occur in little over $50 \%$ of health teams that joined the PMAQ [21]. 
Regarding data found from the present study, it could be observed that, from data contained in the evaluation of the 1st PMAQ-AB cycle, the state of Maranhão was the only different from the others, identifying that the most Health Units of this State did not carry out campaigns for the detection of oral lesions and referral of suspected oral cancer cases. In addition, the State of Bahia, followed by Piauí, were those that most registered and monitored suspected or confirmed oral cancer cases. However, although campaigns were carried out by most Primary Care Units for the same evaluation period (2011/2012), data available for northeastern Brazil show that the recording and follow-up of suspected oral cancer cases are not are performed and even less documented for the purpose of proving suspected or confirmed cases.

A fact that draws attention, and even more recent, from the evaluation of the second PMAQ-AB cycle (2013/2014), is that the state of Bahia, despite having the highest percentage of Oral Health Teams with adherence to PMAQ, is also the state with the lowest percentage of documentation for the purpose of proving suspected or confirmed oral cancer cases and the one that is most unaware of the registration and follow-up of cases.

In an analysis from 2002 to 2013, Perea et al. [22] found that the mortality trend due to oral and pharyngeal cancer increased over time only in the northeastern region, while for the other regions of the country, both incidence and mortality rates have been decreasing. These findings, added to results obtained in the present study, draw attention to the need for reorganization of oral health care, especially that offered by Primary Health Care, and there is a need for effective and permanent planning of tracking of suspected cases with the training and awareness of human resources on this problem before it severely compromises the health of individuals and the health care system. The denial of the need for urgent intervention is already a serious public health problem.

Based on these data, it could be inferred that the northeastern region of Brazil needs to carry out public awareness campaigns about the severity hidden behind minimal oral changes and about the importance of visiting the dentist in Basic Health Units and make human resources in oral health aware of the importance of proposing campaigns on the subject, especially at community meetings. Most importantly, suspected or diagnosed cases should be registered and monitored. These are the patients who will deserve more attention and their follow-up is fundamental to guarantee the chances of cure. And the knowledge of these cases must be through the registration and issuance of documentation so that patients can be guaranteed about their treatment and medical follow-up.

The Ministry of Health has proposed the creation of National Cancer Control Programs [23] that are not restricted only to clarification and prevention of the disease, but that provide clinical screening of the assisted population, allowing identifying individuals with greater risk of developing the pathology. For example, the National Tobacco Control Program (PNCT) aims to reduce the prevalence of smoking and, consequently, morbidity and mortality related to neoplasms from this habit [5]. Regarding the Registry and follow-up of confirmed cases and documentary evidence, it was possible to verify that in northeastern Brazil, only $43.9 \%$ of Basic Health Care Teams do it, and of these, only $20.7 \%$ can prove them by means of documents in the first cycle. For the second cycle, this percentage was even lower, $23 \%$ and $13.6 \%$, respectively. Corroborating this information, a study showed that the northeastern region of Brazil has one of the worst performances, only behind the northern region, suggesting that, in these two regions, access to oral health is predominantly established by emergency and complaintmodeled services [13].

These findings are of concern, and it is essential to improve the quality of these registries and follow-up of suspected or confirmed oral cancer cases, taking into account that, in 2018, in the northeastern region of Brazil, the fourth highest estimated rate of oral cancer incidence among men and the third among women were observed [5].

It is noteworthy that the presence of documentary evidence of activities was less frequent than the declaration of their accomplishment, denoting the need to improve mechanisms that favor this verification.

It is also noteworthy that the registration and follow-up of suspected or confirmed oral cancer cases constitutes a local management tool and this information can support the decision-making process in the planning of actions aimed at its early diagnosis and immediate treatment. Thus, these data can contribute to the organization and qualification of the oral health care network.

Despite the efforts, the increase in the number of teams and incentives for qualification and access to 
$A B$ services for oral cancer in northeastern Brazil, there is evidence that changes in the oral health work process are incipient $[23,24]$. In addition, this study suggests the possibility that there may be other variables that may be interfering with the assistance to users with suspected oral cavity injuries such as lack of experience of health professionals, as well as access to early diagnostic exams. Therefore, further studies should be carried out to elucidate these and other issues inherent to oral cavity neoplasms.

The use of secondary data may be considered a study limitation, as this information is subject to errors due to weaknesses in completing the information. In addition, there were no responses for some variables analyzed in the present study.

The incompleteness of data is often reported in surveys with secondary data. A study also carried out in national databases presented incomplete data on the information records for all individuals in some of the variables of interest in the national Hospital Cancer Registry system (INHC) of INCA [25].

However, in the present study, it was emphasized that there were no expressive sample losses and the adopted design gave the description of oral health actions promoted by Health Care Teams of northeastern Brazil regarding oral cancer.

It was verified that Family Health Teams in the northeastern region of Brazil need to improve campaigns to detect and monitor suspected / confirmed oral cancer cases. In addition, it was observed that it is difficult for Health Teams in the northeastern region of Brazil to maintain the record and prove, through documents, the activities performed. Such a reality could compromise the quality of care, the service evaluation and the construction of new health policies with a view to improving the oral health of the population.

Therefore, the results of this research allows us reflecting on the weaknesses of Primary Care in this Brazilian region in coordinating oral health care, specifically considering early diagnosis and immediate treatment of suspected or confirmed oral cancer cases.

However, it is important to emphasize that PMAQ-AB develops through continuous evaluation cycles and the data obtained in the next cycles will allow future comparisons and the evaluation of possible changes in this scenario.

\section{CONCLUSION}

In the northeastern region of Brazil, most Primary Health Care Teams perform campaigns to detect oral lesions and refer suspected oral cancer cases. However, only few of them register the follow-up of suspected / confirmed oral cancer cases, and documents that prove the accomplishment of these actions are infrequent.

Collaborators

LV RODRIGUES, author and creator of the project. ILA RIBEIRO and APL PROTÁSIO, project correction and assistance in statistical analysis. AG VALENÇA, correction and orientation of the project and assistance in oral health analysis. EA LIMA NETO, project orientation and assistance in statistical analysis.

\section{REFERENCES}

1. Rehem TCMSB, Egry EY. Internment for conditions suitable for primary healthcare in Sao Paulo state. Ciênc \& Saúde Coletiva. 2011;16:4755-4766. http://dx.doi.org/10.1590/S14 13-81232011001300024

2. Brasil. Ministério da Saúde. Cadernos de atenção básica: saúde bucal. Brasília: Ministério da Saúde; 2006 [citado 2018 Nov 10]. Disponível em: <http://bvsms.saude.gov.br/bvs/ publicacoes/saude_bucal.pdf>.

3. Brasil. Ministério da Saúde. Diretrizes da política nacional de saúde bucal. Ministério da Saúde Brasília; 2004 [citado 2018 Nov 10]. Disponível em: <http://189.28.128.100/dab/docs/ publicacoes/geral/diretrizes_da_politica_nacional_de_saude_ bucal.pdf>.

4. Corrêa EH, Abegg C, Keller CR, Pascoal PM. Impacto das equipes de saúde bucal da Estratégia da Saúde da Família na saúde bucal de adolescentes do sul do Brasil. Ciênc Saúde Coletiva. 2016; 21(5):1607-1616. http://dx.doi. org/10.1590/1413-81 232015215.07822015

5. INCA. Estimativa 2018: incidência de câncer no Brasil. Rio de Janeiro: INCA; 2018 [citado 2018 Nov 10]. Disponível em: <https://www.inca.gov.br/sites/ufu.sti.inca.local/files//media/ document//estimativa-incidencia-de-cancer-no-brasil-2018. $p d f>$.

6. INCA. Estimativa da incidência de câncer para 2008 no Brasil e nas cinco regiões. Rio de Janeiro: INCA; 2008.

7. Maruccia M, Onesti MG, Parisi P, Cigna E, Troccola A, Scuderi N. Lip cancer: a 10-year retrospective epidemiological study. Anticancer Res. 2012;32(4):1543-1546.

8. Onizawa K, Nishihara K, Yamagata K, Yusa H, Yanagawa T, Yoshida $\mathrm{H}$. Factors associated with diagnostic delay of oral 
squamous cell carcinoma. Oral Oncol. 2003;39(8):781-8. http://dx.doi.org/10.1016/S1368-8375(03)00075-7

9. Sousa FB, Fernandes CP, Silva PGB, Alves APNN. Oral cancer from a health promotion perspective: experience of a diagnosis network in Ceará. Braz Oral Res. 2014;28:1-8. http://dx.doi.org/10.1590/1807-3107BOR-2014

10. Brasil. Ministério da Saúde. Departamento de Atenção Básica. Programa Nacional de Melhoria do Acesso e da Qualidade da Atenção Básica (PMAQ): manual instrutivo. Brasília: Ministério da Saúde; 2011 [citado 2018 Nov 10]. Disponível em: <http://189.28.128.100/dab/docs/portaldab/documentos/ Manual_Instrutivo_3_Ciclo_PMAQ.pdf>.

11. Brasil. Ministério da Saúde, Departamento de atenção Básica. Gestão da Atenção Básica Retratos da Atenção Básica n. 2. Gestão da Atenção Básica. Volume 3 - Ações da Gestão para Qualificação das Equipes. Brasília: Ministério da Saúde; 2015.

12. Costa AM, Santos FP, Melo EA. Por uma atenção básica para o SUS. Divulg Saúde Debate. 2014;51:4-7.

13. Casotti E, Contarato PC, Fonseca ABM, Borges PKO, Baldani $\mathrm{MH}$, Casotti E, et al. Dental care in Brazil: an analysis based on PMAQ-AB External Evaluation. Saúde Debate. 2014;38:140-57. http://dx.doi.org/10.5935/0103-1104.2014S011

14. Brasil. Ministério da Saúde. Portal do Departamento de Atenção Básica. Programa Nacional de Melhoria do Acesso e da Qualidade da Atenção Básica (PMAQ). Brasília: Ministério da Saúde [citado 2018 Nov 10]. Disponível em: <http://dab. saude.gov.br/portaldab/ape_pmaq.php>.

15. SPSS I. IBM Knowledge Center 2001 [citado 2018 Nov 10]. Disponível em: <http://www-01.ibm.com/support/ knowledgecenter/SSLVMB_20.0.0/com.ibm.spss.statistics.cs/ twostepcluster_table.htm>.

16. Brasil. Ministério da Saúde. Secretaria-Executiva. Departamento de Regulação, Avaliação e Controle de Sistemas. Pnass: Programa Nacional de Avaliação de Serviços de Saúde. Brasília: Ministério da Saúde; 2015 [citado 2018 Nov 10]. Disponível em: <http://bvsms.saude.gov.br/bvs/publicacoes/ pnass_programa_nacional_avaliacao_servicos.pdf >.

17. Brasil. Ministério da Saúde. Portal do Departamento de Atenção Básica. Brasília: Ministério da Saúde; 2015 [citado 2018
Set 14]. Disponível em: <http://dab.saude.gov.br/portaldab/ historico_cobertura_sf.php.

18. Soares FF, Figueiredo CRV de, Borges NCM, Jordão RA, Freire $\mathrm{M}$ do CM. Atuação da equipe de saúde bucal na estratégia saúde da família: análise dos estudos publicados no período 2001-2008. Ciênc Saúde Coletiva. 2011; 16:3169-3180. http://dx.doi.org/10.1590/S1413-81232011000800017

19. Santos LPS, Carvalho FS, Carvalho CAP, Santana DA Características de casos de câncer bucal no estado da Bahia, 1999-2012: um estudo de base hospitalar. Rev Bras Cancerol 2015;61:7-14.

20. FAPITEC/SE. Pesquisa aponta que mulheres estão mais susceptíveis ao câncer de boca. 2015 [citado 2018 Set 14]. Disponível em: <https://www.t4h.com.br/noticias/pesquisaaponta-que-mulheres-estao-mais-susceptiveis-ao-cancer-deboca/s.

21. Sobrinho L, Martelli PJ de L, Albuquerque MSV, Lyra TM, Farias SF. Access and quality: evaluation of Oral Health Teams participating PMAQ-AB 2012 in Pernambuco. Saúde Deb. 2015;39:136-146. http://dx.doi.org/10.1590/0103-110 420151040209

22. Perea LME, Peres MA, Boing AF, Antunes JLF. Trend of oral and pharyngeal cancer mortality in Brazil in the period of 2002 to 2013. Rev Saude Publica. 2018;52:10. http://dx.doi. org/10.11606/S1518-8787.2018052000251

23. Petersen PE. Oral cancer prevention and control-the approach of the World Health Organization. Oral Oncol. 2009;45(4-5):454-60. http://dx.doi.org/10.1016/j.oraloncology.2008.05.023

24. Scherer $\mathrm{Cl}$, Scherer MD dos A. Advances and challenges in oral health after a decade of the "Smiling Brazil" Program. Rev Saúde Pública. 2016;49. http://dx.doi.org/10.1590/S0034-8 910.2015049005961

25. Ribeiro ILA, Medeiros JJ, Rodrigues LV, Valença AMG, Neto L, Andrade $E$, et al. Factors associated with lip and oral cavity cancer. Rev Bras Epidemiol. 2015;18(3):618-29. http://dx.doi. org/10.1590/1980-5497201500030008

Received on: 15/6/2018 Final version resubmitted on: 30/10/2018 Approved on: 19/11/2018 